J. Clin. Chem. Clin. Biochem.

Vol. 16, 1978, pp. 289-291

\title{
Evaluation of the Enzymatic Ammonia Method for Urine on the Du Pont Automatic Clinical Analyzer
}

\author{
By F. R. Hindriks and A. Groen \\ University Hospital Groningen, Central Laboratory for Clinical Chemistry
}

(Received November 7/December 19, 1977)

\begin{abstract}
Summary: The enzymatic method for ammonia with the Du Pont Automatic Clinical Analyzer was tested in our laboratory. The method is very suitable for urine samples although the method was released by Du Pont only for plasma samples. The results correlated well with those obtained by a method based on the Berthelot indophenol reaction and by a method based on the use of an ammonium electrode, which has an ammonium ion selective membrane. The day-to-day coefficient of variation is about 2 and $4 \%$ at concentration levels of 100 and $50 \mu \mathrm{mol} / 1$ respectively. The measured and relative ammonia concentration are linearly related. Recovery of added known amounts of ammonium is complete and no interference from glucose, urea, creatinine and uric acid could be demonstrated. Recommendations are given for handling blood and urine samples before analysis.
\end{abstract}

\section{Evaluation der enzymatischen Methode für Harn-Ammoniak am Du Pont Automatic Clinical Analyzer}

Zusammenfassung: Die enzymatische Methode für Ammoniak mit dem Du Pont Automatic Clinical Analyzer wurde in unserem Laboratorium getestet. Die Methode ist sehr geeignet für Harnproben, obwohl sie von Du Pont nur für Plasmaproben angegeben wurde. Die Ergebnisse stimmten gut mit denen überein, die mit einer Methode auf der Grundlage der Berthelot'schen Indophenolreaktion bzw. mit einer ammoniumionensensitiven Elektrode erhalten wurden. Die Präzision von Tag zu Tag entsprach bei Konzentrationen von 100 bzw. $50 \mu \mathrm{mol} / 1$ einem Variationskoeffizienten von 2 bzw. 4\%. Die gemessene und relative Ammoniakkonzentration sind einander linear. Die Wiederfindung zugesetzten Ammoniaks ist vollständig. Glucose, Harnstoff, Kreatinin und Harnsäure zeigten keine Störung der Methode. Empfehlungen für die Handhabung von Blut- und Harnproben vor der Analyse werden gegeben.

\section{Introduction}

Ammonia is produced in the liver by oxidative deamination of amino acids, resulting in the formation of a keto acid and ammonia. By urea synthesis ammonia is rapidly removed and detoxified. In the absence of severe liver damage most of the free ammonia is formed in the intestinal tract, from urea by the action of bacterial ureases, and from protein in the diet. Ammonia is also produced in the distal renal tubules from glutamine by the action of glutaminase. The liberated ammonia immediately combines with hydrogen ions to form ammonium ions. The production of ammonium ions allows the excretion of excéss anions and hydrogen ions without the corresponding loss of fixed base (sodium and potassium). In clinical practice, the estimation of urinary ammonia gives a measure of ammonia production by the distal renal tubules in response to acidosis. Together with the titratable acidity it gives a measure of the extent to which the body is able to conserve sodium and potassium while excreting excess anions and hydrogen ions.

With these clinical implications in mind, it was our aim to test the enzymatic method for the determination of ammonia in urine. For a number of years, it has been possible to measure ammonia in blood or plasma using glutamic dehydrogenase (EC 1.4.1.3) in the presence of 2-oxoglutarate $(1,2,3)$.

\section{Materials and Methods}

\section{Urine}

The urine samples were carefully collected to prevent contamination and stored at $-20^{\circ} \mathrm{C}$ or used immediately.

Berthelot indophenol method

Ammonia was determined following a method (4) based on the Berthelot indophenol reaction (5). 
Ammonium electrode method

Ammonia was determined following a method (6) based on the use of a Philips ammonium electrode (IS $560-\mathrm{NH}_{4}$ ), which has an ammonium ion selective membrane. A Philips reference electrode (R 44/2-SD/1) and Philips digital voltmeter (PW 9413) which is a general purpose meter in common use as a $\mathrm{pH}$ meter, were also used.

The IL 343 flame photometer was used for the determination of potassium in urine.

\section{Enzymatic method}

The Du Pont Automatic Clinical Analyzer ammonia method is an adaption of the enzymatic method of van Anken \& Schiphorst (7). NADPH is substituted for NADH to eliminate interferences from other NADH-consuming reactions (8). Glutamate dehydrogenase (EC 1.4.1.3) catalyzes the condensation of ammonia and 2-oxoglutarate with simultaneous oxidation of reduced nicotinamide adenine dinucleotide phosphate (NADPH). The decrease in absorbance at $340 \mathrm{~nm}$, due to the disappearance of NADPH, is directly proportional to the ammonia concentration in the sample.

All urine samples were diluted immediately before determination as follows: $0.1 \mathrm{ml}$ urine was added to $5.0 \mathrm{ml}$ twice-distilled water.

\section{Results and Discussion}

\section{Precision}

Within-run precision was assessed by assaying a number of replicates of ammonium chloride solutions at two concentrations. Day-to-day precision was assessed by assaying ammonium chloride solutions at two concentrations on 15 consecutive working days. The results are given in table 1 .

Tab. 1. Precision of the enzymatic ammonia method

\begin{tabular}{rlll}
\hline & $\begin{array}{l}\text { Mean } \\
(\mathrm{mmol} / \mathrm{l})\end{array}$ & $\begin{array}{l}\text { SD } \\
(\mathrm{mmol} / \mathrm{l})\end{array}$ & $\begin{array}{l}\mathrm{CV} \\
(\%)\end{array}$ \\
\hline Within-run & & & \\
$\mathrm{N}=12$ & 40.8 & 1.99 & 4.9 \\
15 & 43.3 & 2.35 & 5.4 \\
9 & 105.8 & 1.86 & 1.8 \\
16 & 103.8 & 2.18 & 2.1 \\
& & & \\
Day-to day & & & 3.9 \\
$\mathrm{~N}=15$ & 47.1 & 1.83 & 2.3 \\
15 & 104.9 & 2.44 &
\end{tabular}

Tab. 2. Accuracy of the enzymatic ammonia method. Concentrations and percentage recovery are given for ammonium in urine spiked with $24.67 \mathrm{mmol} / \mathrm{l}$ ammonium chloride.

\begin{tabular}{lll}
\hline $\begin{array}{l}\text { Original } \\
\text { concentration }\end{array}$ & \multicolumn{2}{l}{ Addition 24.67 mmol/1 } \\
(mmol/l) & $\begin{array}{l}\text { Total concentration } \\
(\mathrm{mmol} / \mathrm{l})\end{array}$ & $\begin{array}{l}\text { Recovery } \\
(\%)\end{array}$ \\
\hline 0 & 26.16 & 106.0 \\
8.98 & 35.14 & 106.0 \\
13.46 & 39.73 & 106.5 \\
25.35 & 51.46 & 105.8 \\
30.86 & 56.30 & 103.2 \\
40.60 & 65.99 & 103.0 \\
Mean \pm SD & & $105.1 \pm 1.55$ \\
\hline
\end{tabular}

\section{Accuracy}

A known amount of an ammonium chloride solution was added to several urine samples. The same procedure was used for plasma, by the addition of small quantities of ammonium chloride to plasma samples. The recovery of ammonium by the enzymatic method was complete. The results are given in tables 2 and 3.

Tab. 3. Accuracy of the enzymatic ammonia method.

Concentrations and percentage recovery are given for ammonium in plasma spiked with $90.9 \mu \mathrm{mol} / 1$ ammonium chloride.

\begin{tabular}{lll}
\hline $\begin{array}{l}\text { Original } \\
\text { concentration }\end{array}$ & Addition $90.9 \mu \mathrm{mol} / 1$ & \\
$(\mu \mathrm{mol} / \mathrm{l})$ & $\begin{array}{l}\text { Total concentration } \\
(\mu \mathrm{mol} / \mathrm{l})\end{array}$ & $\begin{array}{l}\text { Recovery } \\
(\%)\end{array}$ \\
\hline 0 & 92 & 102.1 \\
0 & 90 & 99.0 \\
20 & 112 & 101.2 \\
22 & 114 & 101.2 \\
26 & 120 & 103.4 \\
28 & 122 & 103.4 \\
41 & 130 & 97.9 \\
Mean \pm SD & & $101.0 \pm 2.05$ \\
\hline
\end{tabular}

\section{Linearity}

For the enzymatic method there exists a good linearity between the measured $(y)$ and the relative ammonium concentration ( $\mathrm{x}$ ) to approximately $1000 \mu \mathrm{mol} / 1$. The linearity was tested by running ammonium chloride solutions in triplicate at seven concentrations ranging from 0 to $100 \mu \mathrm{mol} / 1(\mathrm{y}=\mathrm{a}+\mathrm{b} \cdot \mathrm{x} ; \mathrm{N}=7 ; \mathrm{a}=0.1348$ $\mu \mathrm{mol} / 1 ; \mathrm{b}=1.036 ; \mathrm{r}=0.9989$ and $\mathrm{N}=7 ; \mathrm{a}=0.7952$ $\mu \mathrm{mol} / \mathrm{l} ; \mathrm{b}=1.0079 ; \mathrm{r}=0.9999)$ and from 0 to 1000 $\mu \mathrm{mol} / 1(\mathrm{y}=\mathrm{a}+\mathrm{b} \cdot \mathrm{x} ; \mathrm{N}=7 ; \mathrm{a}=8.019 \mu \mathrm{mol} / \mathrm{l} ; \mathrm{b}=1.0070$; $\mathrm{r}=0.9999$ and $\mathrm{N}=7 ; \mathrm{a}=7.278 \mu \mathrm{mol} / \mathrm{l} ; \mathrm{b}=1.0700$; $r=0.9999$ ).

\section{Comparison study}

\section{Berthelot indophenol method vs. enzymatic method} (fig. 1)

The slope is 1.0266 , which indicates a proportional error of $2.7 \%$. Constant error is estimated at only $-0.1394 \mathrm{mmol} / \mathrm{l}$ by the $\mathrm{y}$ intercept. The correlation coefficient is 0.9969 or nearly ideal. The standard deviation of the differences $\left(\mathrm{s}_{\mathrm{yx}}\right)$ is estimated at 1.11 $\mathrm{mmol} / 1$. For an ammonium concentration of $25.0 \mathrm{mmol} / 1$ determined with the indophenol method, the enzymatic method will give an average value of $25.5 \mathrm{mmol} / \mathrm{l}$ and there exists $95 \%$ certainty that the value will be between 23.3 and $27.7 \mathrm{mmol} / 1\left( \pm 2 \mathrm{~s}_{\mathrm{yx}}, \pm 2.22 \mathrm{mmol} / \mathrm{l}\right)$.

\section{Electrode method vs. enzymatic method (fig. 2)}

The slope is 0.9989 , which indicates a proportional error of $0.1 \%$. Constant error is estimated at $1.5659 \mathrm{mmol} / 1$ by the $y$ intercept. The correlation coefficient is 0.9954 . The standard deviation of the differences $\left(s_{y x}\right)$ is 


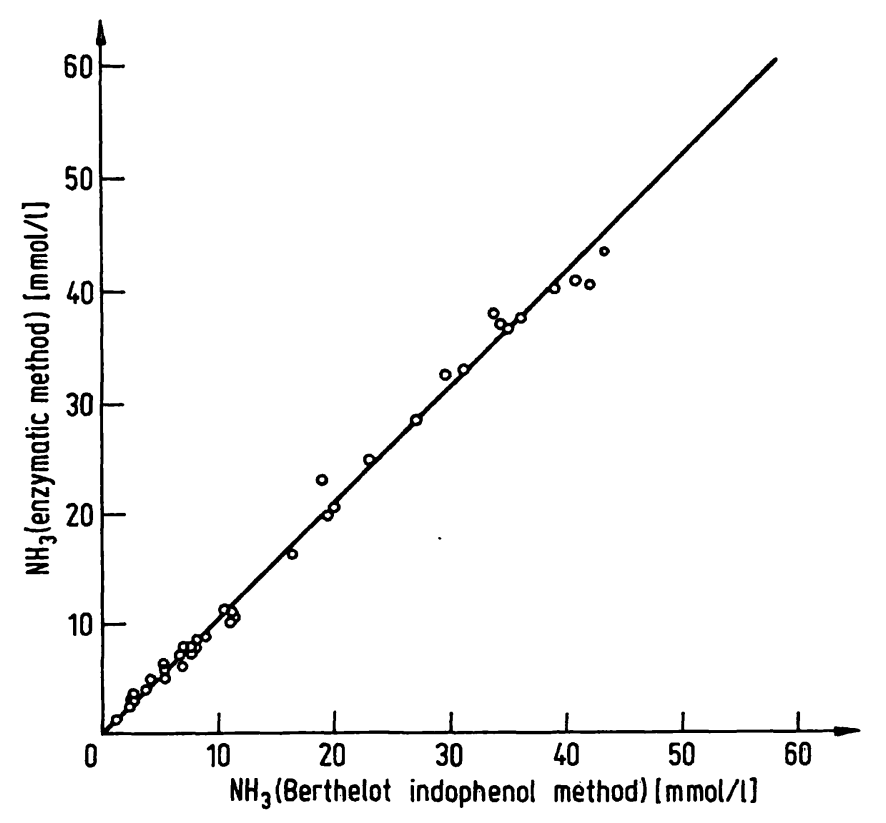

Fig. 1. Comparison of the ammonia concentration obtained by the Berthelot indophenol method vs. the enzymatic method. See text for statistical parameters of the regression line.

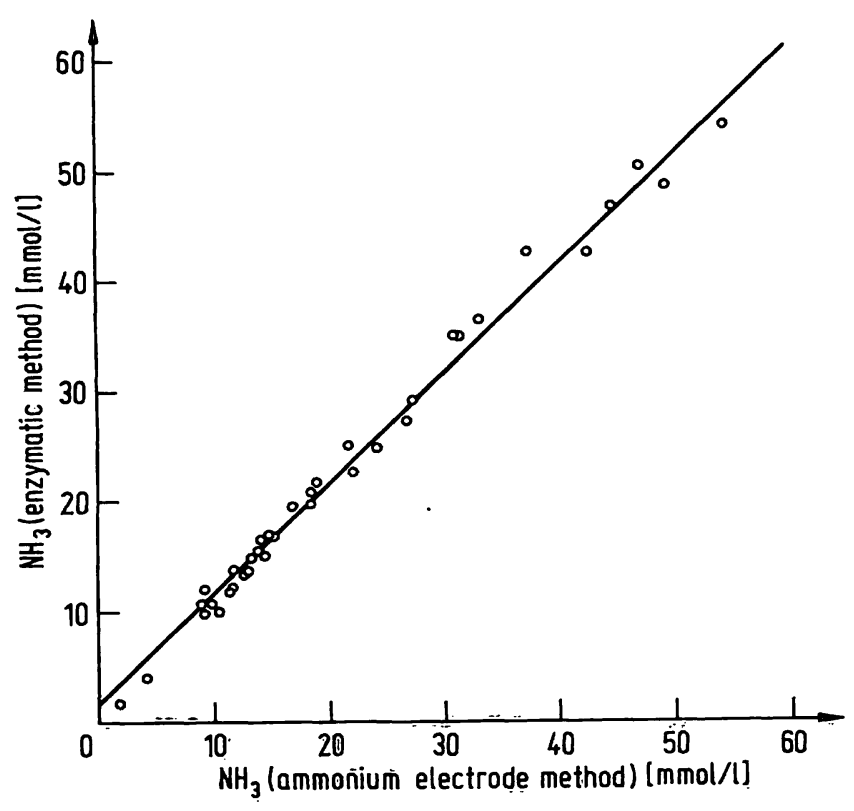

Fig. 2. Comparison of the ammonia concentration obtained by the electrode method vs. the enzymatic method. See text for statistical parameters of the regression line. estimated at $1.65 \mathrm{mmol} / 1$. For an ammonium concentration of $25.0 \mathrm{mmol} / 1$ determined with the ammonium electrode method, the enzymatic method will give an average value of $26.5 \mathrm{mmol} / 1$ and there exists $95 \%$ certainty that the value will be between 23.2 and 29.8 $\mathrm{mmol} / \mathrm{l}\left( \pm 2 \mathrm{~s}_{\mathrm{yx}}, \pm 3.30 \mathrm{mmol} / \mathrm{l}\right)$.

\section{Interfering substances}

The following substances have been shown to have no measurable effect on the enzymatic method at concentrations which can be expected in human urine samples: glucose, urea, creatinine and uric acid. Neither there was any interference from other buffers (tris, glycine and methylaminopropanol), which were used on the instrument for other analyses between duplicate ammonia determinations.

In conclusion the enzymatic method is in our opinion a viable method for the determination of ammonia in urine and plasma samples.

It is recommended that urine samples are kept in stoppered sterile bottles. In this way non-infected urine can be stored at room temperature for at least $24 \mathrm{~h}$ without any change in ammonia concentration. All glassware should be made ammonia free by immersion in chromic acid, followed by thorough washing with tap water and twice distilled water.

To prevent coagulation of blood samples heparin should be used. Heparin inhibits the activity of adenylic acid deaminase and prevents the metabolism of adenylic acid which produces ammonia. Blood samples should be chilled in ice immediately after venipuncture. Within 15 min plasma should be separated from the cells. The plasma samples can be kept not longer than $20 \mathrm{~min}$ at room temperature before analysis.

\section{Acknowledgements}

The authors wish to express their gratitude to Mr. E. E. Ligeon, Mr. M. de Ruyter and Mr. J. Keizer for their technical assistance, Mr. J. J. Hoks for drawing and photographing of the figures and Du Pont Company for providing reagents.

\section{References}

1. Mondzac, A., Ehrlich, G. E. \& Seegmiller, J. E. (1965), J. Lab. Clin. Med. 66, 526-531.

2. Oreskes, I., Hirsch, C. \& Kupfer, S. (1969), Clin. Chim. Acta $26,185=188$

3. Reichelt, K. L., Kvamme, E. \& Tveit, B. (1964), Scand. J: Clin. Lab. Invest. 16, 433-439.

4. Gips, C. H., Reitsema, A. \& Wibbens-Alberts, M. (1970), Clin. Chim. Acta 29, 501-505.
5. Berthelot, M. P. E. (1859), Répert. Chim. Appl. 284.

6. Hoge, J. H. C., Hazenberg, H. J. A. \& Gips, C. H. (1974), Clin. Chim. Acta 55, 273-279.

7. Anken, van H. C. \& Schiphorst, M. E. (1974), Clin. Chim. Acta $56,151-159$.

8. Fonseca-Wollheim, da F. (1973), this J. 11, 421-425. 
. 